\title{
Vasco Graça Moura e sua "Bacante": o (des)Oriente (per)Verso de um poeta acorrentado
}

\author{
Vasco Graça Moura and his "Bacante": \\ the disorient East and the wicked Verse of a chained poet \\ José Ricardo da Costa \\ Universidade Federal do Rio Grande do Sul - Porto Alegre - Rio Grande do Sul - Brasil
}

$\diamond$

\begin{abstract}
Resumo: O poeta Vasco Graça Moura destacou-se em sua carreira como ensaísta, tradutor, poeta e escritor, dividindo seu tempo com a política portuguesa e a internacional. Esta participação deixou fortes marcas em sua obra, como veremos neste ensaio, que busca um aprofundamento sobre as significações evocadas no poema "a bacante" (2006, p. 128). É notável, ao fim de sua vida, como a reflexão sobre a condição política e cultural portuguesa e europeia, frente ao alargamento de fronteiras e hibridização do início do século XXI, marcam de maneira indelével a obra do escritor, situando-o no cenário da poesia pós-moderna, como buscaremos mostrar com este trabalho.
\end{abstract}

Palavras-chave: Vasco Graça Moura; Poesia pós-moderna; Identidade europeia

\begin{abstract}
The poet Vasco Graça Moura excelled in his career as an essayist, translator, poet and writer, dividing his time with international and Portuguese politic. This participation has left indelible marks in his work, as we shall see in this essay, which seeks a deepening of the meanings evoked in the poem "a bacante" (2006, p. 128). It is noteworthy, at the end of his life, the way as the reflection on the political and cultural Portuguese and European's condition, opposite the extension of XXI century beginning's boundaries and hybridization marks indelibly the writer's work, placing him in the setting of postmodern poetry, as we try to show with this paper.
\end{abstract}

Keywords: Vasco Graça Moura; Postmodern poetry; European identity

O português Vasco Graça Moura (1942-2014) dividiu sua trajetória entre as atividades de político (tendo, entre diversos cargos, ocupando o de deputado na União Europeia entre os anos de 1999 e 2009), articulador cultural (estando à frente do Centro Cultural de Belém), e literato, quer como ensaísta político, tradutor (Medalha de ouro de Florença 1997 por sua tradução de Dante), romancista e poeta. Esta multiplicidade de faces estendeu-se em cada uma das perspectivas de sua vida, fazendo de Moura um legítimo herdeiro do homem renascentista, poliédrico em sua riqueza de aspectos, com mais de sessenta obras entre poesia, romance, ensaística e teatro, com inúmeros prêmios, dentre os quais, o Prêmio Pessoa (1995).

Já ao fim da vida, um dos últimos motes de sua luta política foi o da definição de melhores demarcações ao processo de abertura da União Europeia, objeto de sua última obra, A identidade Cultural Europeia (2014, s.p.), em que trata, a um só tempo, da origem das raízes ocidentais e da progressiva crise econômica acarretada pelo modelo político adotado pelos países da Europa no processo de abertura para novas nações no G15 (Grupo dos 15).

Notáveis por seu papel na história das descobertas e navegações, os países ibéricos frequentemente são relegados a um segundo plano na Europa. Neste sentido, a participação de Moura na política e na cultura foi fundamental para o estabelecimento de Portugal, país de economia frágil, em um grupo que conta com algumas das maiores potências mundiais, como percebemos em uma de suas últimas entrevistas, dada ao blog português Gladius (o autor faleceu em 27 de abril de 2014). 
Fui dez anos deputado europeu e os dois mandatos coincidiram com a Europa dos 15 e, depois, com a Europa dos 27. Esta alteração do perímetro geográfico teve consequências extremamente complicadas em relação à ideia que eu próprio fazia da Europa. Eu pertenço a uma geração em que não se punha a questão de ser europeu - ser europeu era natural. Mesmo quando Portugal passou a viver, a partir do 25 de Abril, uma nova fase da sua história, não podemos dizer que até então não fôssemos europeus - fomos sempre europeus (MOURA, 2014, s.p.).

Pode-se facilmente aquilatar, nas palavras de Moura, a percepção do homem das ideias a respeito do olhar excludente por parte da União Europeia sobre os países ibéricos, o qual tentou teórica e politicamente rechaçar, durante sua trajetória. O escritor buscou permanentemente conciliar a luta contra o espírito xenofóbico e a diluição das tradições do que ele próprio confirma como "Velho Mundo". Esta oposição entre liberdade de pensamento e preservação de valores identitários marcou fortemente seus últimos trabalhos, como veremos ao traçar um paralelo reflexivo entre poemas da obra "poesia 2001/2005" (2006), que percebemos como uma tentativa (que beira o quixotismo) de celebrar a herança cultural do Velho mundo, a presença do Novo Mundo e de um Oriente delimitados pelo olhar do poeta.

Busca-se, neste ensaio, demarcar esta oscilação emocional e reflexiva e esta contradição, presentes em "poesia 2001/2005" (2006), de maneira a localizar o trabalho do escritor no cenário da contemporaneidade, ou, na medida em que extrapola os limites deste, em uma contemporaneidade hiperbólica, ou hipercontemporaneidade, enquanto fluxo de pensamento e saberes em constante diálogo questionador com o passado. Para tanto, além de comentar ligeiramente passagens de outros poemas, analisar-se-á mais atentamente "a bacante" (MOURA, 2006, p. 128).

Assim, em "HERÓDOTO E TUCÍDIDES EM UM CAMONIANO POETA", estuda-se a maneira como a trajetória do escritor se confunde com a do político e a do narrador de seu tempo. Analisa-se ainda a maneira como Moura a um só tempo celebra e ironiza a herança clássica, na medida em que recupera suas construções, em "O RITMO ENQUANTO METÁFORA". Em "DEUSES E REIS: IMAGEM E INTERTEXTUALIDADE", observa-se ainda como o poema de Moura torna-se uma irônica celebração da herança europeia. E, finalmente, em "O PROMETEICO, O (DES)ORIENTE E O (PER)VERSO", tem-se um poeta que reclama para si o fado de Prometeu, acorrentado pelos deuses, a vislumbrar constantemente o futuro do homem que tenta emancipar.

\section{Heródoto e Tucídides em um camoniano poeta}

Herdeiro da tradição do sábio de Halicarnassos, Moura tenta, em sua trajetória, ocupar o papel de narrador e poeta de seu tempo. Se Heródoto, ao inaugurar o que se compreende, ocidentalmente, como história, tenta abster-se da crítica para recuperar o passado, Moura, assim como Tucídides, bebe amplamente da fonte do pensamento crítico, sem quaisquer peias de afastar-se da posição de mediador, própria dos políticos, em defesa de ideias fulcralmente europeístas e eurocentristas. Gagnebin (1997) fala de um "Pai da História" muito próximo do poeta lusitano:

\footnotetext{
Heródoto retoma e transforma a tarefa do poeta arcaico: contar os acontecimentos passados, conservar a memória, resgatar o passado, lutar contra o esquecimento. Tarefa essencial que a voz do poeta - numa sociedade sem escrita como era a Grécia arcaica - encarnava, e que continuou também no texto poético escrito. Tarefa que religa o presente ao passado, fundando a identidade de uma nação ou de um indivíduo [...] (GAGNEBIN, 1997, p. 17-18).
}

Moura intenta, a um só tempo, um embate entre os imagos do lusitano com os signatários das ricas (ainda que fragilizadas) nações da Europa franco-saxônica. $\mathrm{O}$ cenário desta empreitada não é nada promissor, toma Portugal como parte de uma Europa cada vez mais fragmentada, alvo de múltiplas invasões de culturas orientais, em tempos de economia globalizada. Em sua construção lírica, o autor entremeia o logos à poïesis, tomando para si a missão do poeta arcaico, a exemplo do trabalho de Heródoto, que operou um deslocamento entre dois tipos de narrativas, como fala Gagnebin, que correspondem a duas formas de tempo: "[...] uma narrativa mítica, lendária, sem cronologia possível, que remete ao tempo afastado dos deuses e dos homens; e [...] uma narrativa 'histórica' (de um tempo pesquisável e pesquisado)" (2007, p. 19).

Este trânsito entre fato e idealização, sentimento e imaginação é o claro produto de uma posição privilegiada ocupada pelo poeta, a de narrador de seu tempo, em um processo em que sua objetividade, como nos lembrará ainda Gagnebin (2007, p. 24) será constantemente "minada pelo fluxo da narrativa". Moura reconhece a similitude de sua missão com a de Camões (MOURA, 2014, s.p.), a cantar as façanhas de D. Sebastião, mas sabe que sua posição se confunde, amiúde, com a posição do governante mítico de Portugal, na medida em que colabora para a construção dos rumos de seu país na esfera política. Não deixará, destarte, a despeito deste comprometimento com o logosófico universo dos 
estadistas, de comprometer-se com o idiossincrático fado do poeta.

A Portugal está a faltar muita poesia. Não enche a barriga, mas pode ajudar a encher o espírito. Tudo o que imponha uma dialética de opostos é importante. Pelo menos um embrião de conflito. A unanimidade é a mais banal e empobrecedora das situações (MOURA, 2014, s. p.)

Paz localiza o poema como um exercício em direção à alteridade, na medida em que "as palavras do poeta, justamente por serem palavras, são suas e alheias. Por um lado, são históricas: pertencem a um povo : são algo datável. Por outro lado, são anteriores a toda data: são um começo absoluto" (PAZ, 1972, p. 223). Em suma, "a voz poética, 'a outra voz', é minha voz” (PAZ, 1972, p. 220). É esta percepção da alteridade e este reencontro consigo e com suas raízes a partir do alheio que propõe Moura. E esse reencontro tem como princípio a celebração de múltiplos ritmos, entre o clássico e o popular, passado e futuro que se encontram, entre Velho e Novo Mundo, em uma espiral de cadências que se sucedem e se confundem, na mimese da realidade contemporânea.

\section{0 ritmo enquanto metáfora}

Paz afirma que as palavras "são nossa única realidade, ou pelo menos, o único testemunho de nossa realidade", em uma "rede de pescar palavras" feita, ela também, de palavras (1972, p. 37). Nesta cadência de sons, mesmo o silêncio, lembra o poeta e ensaísta, é "prenhe de signos". Deste comutar entre som e silêncio, impressos na letra para serem, futuramente, expressos na psiquè (alma) do leitor, surgem o ritmo e a musicalidade de um poema. Em "poesia 2001/2005" (2006), Moura mimetiza ritmos e métricas consagrados da lira clássica, como em "a bacante" (2006, p. 128), passeando ainda por construções que imitam as canções de amigo e amante lusas, como em "magusto de ricardo reis" (2006, p. 129), chegando a flertar com os gazais de Lorca, em "sim, ama-me em madrid" (2006, p. 148), ou com os sonetos shakesperianos, em "soneto do jazzband" (2006, p. 147). Esta referência constante a construções consagradas beira o pastiche, como em "imitado de borges" (2006, p. 144), e servirá como um potente recurso metafórico, que o poeta irá alternar com as métricas informes e inauditas, ou mesmo com uma construção quase prosódica, como em "para um blues no Porto" (2006, p. 146).

São elucubrações de ritmo e métrica que suscitam diversos efeitos de estese, onde, como diria Todorov, o campo do interpretável está sempre sob o "risco de se expandir" (1978). O "magusto de ricardo reis" (2006, p. 129), na melhor tradição do trovadorismo português, traz o diálogo entre o eu poético e uma insuspeita escrava lídia (de traços orientais), em que se sucederão metáforas que remetem à lira árcade de Reis, onde é rediviva a figura da misteriosa musa oriental do poeta. Teremos a repetição de um refrão, que, a cada nova estrofe, adquire distintas possibilidades de interpretação, em um ritmo cadentemente crescente, que parece imitar a passagem das estações. Em "sim, ama-me em madrid" (2006, p. 146), vê-se uma construção onde cinco quintetos (versos de arte maior) com rimas interpoladas, irão, ao mesmo tempo, resgatar a obra de Lorca e contradizê-la, na medida em que uma construção rítmica clássica envolve um poema que se estabelece em intertextualidade com o poeta espanhol, conhecido, em sua lira amorosa, por recuperar formatos da poesia popular, em detrimento a construções da erudição clássica. Esta contradição estabelece uma tensão entre forma e conteúdo que irá acentuar o lirismo dos versos. Tal tensão, entre o irônico e o contraditório, se repetirá em "soneto do jazzband" (2006, p. 147), onde o formato do célebre bardo de Avon servirá de suporte a uma ode ao gênero musical norte-americano.

Esta tensão será mais sutil, ao analisarmos detidamente "a bacante" (2006, p. 128). Encontramos como epígrafe um trecho da Ilíada, de Homero, em uma tradução de Alcipe. Moura utiliza-se do recurso intertextual de inserção, onde cada uma das três quintilhas (estrofes de cinco versos de arte menor) será finalizada por um dos versos da epígrafe, recurso utilizado em vários momentos de "poesia 2001/2005" (2006), em uma espécie de ode intertextual: "Logo que a fome apaziguada fica, Com puras libações se acaba a festa: Com vinho copioso em taça rica." (2006, p.128). O poema repetirá, com raras exceções, a metrificação clássica de decassílabos heroicos da Ilíada de Homero, que se alterará apenas em um decassílabo de escansão rítmica informe (o verso 13); e um decassílabo de arte maior (verso 6), um desafiador decassílabo de métrica inaudita, onde podemos perceber quatro sílabas a se destacar, em uma quebra de ritmo notável no poema (verso 12). Temos ainda dois decassílabos sáficos (versos 1 e 5). A ênfase na métrica heroica imprime um ritmo quase bélico, apesar do tema, a princípio, aparentemente trivial, de um banquete.

Da mesma forma, encontra-se uma identidade sonora entre os versos que escapa, em uma das possibilidades de escansão, da métrica heroica ou sáfica (versos 6 e 12). Ainda que o sexto verso, "são só afagos suaves, ira honesta", possa ser metrificado como um decassílabo de arte maior, a escansão mais fácil e direta leva à quinta e décima sílabas mais fortes, caso em que estabelecerá identidade com o décimo segundo verso, "criaturas menores ela explica”, em seu ritmo esdrúxulo à proposta poética.

\footnotetext{
1 Ver a escansão do poema "a bacante”, em apêndice, na página 18.
} 
Nota-se ainda que os dois versos em decassílabo sáfico possuem identidade de construção (versos 1 e 5): "quando o talher pousado é o que resta" e "logo que a fome apaziguada fica". Os versos são formados praticamente pelas mesmas classes de palavras e estrutura frasal (advérbio/sujeito/adjunto adnominal/locução verbal). Desta forma, o poeta chama a atenção para as epígrafes lançadas ao final de cada estrofe, e enseja um primeiro tom prosaico, enquanto nos situa no cenário do poema: um banquete.

Quanto à sonoridade, duas rimas externas consoantes irão predominar no poema: (A) ...esta e (B) ...ica. Rimam consoantemente os versos primeiro, terceiro e quarto da primeira estrofe, em uníssono aos versos sexto, oitavo e décimo da segunda estrofe e aos décimo primeiro e décimo quarto da última estrofe. Da mesma forma, os versos segundo e quinto da primeira estrofe irão rimar consoantemente com os versos nono da segunda estrofe e décimo segundo, décimo terceiro e décimo quinto da última estrofe, rimando soantemente, ainda, com o verso sétimo, da segunda estrofe. Assim, estabelece-se um simulacro das litanias, onde todas as rimas externas são agudas, em um ritmo interpolado. Desenvolve-se vai e vem de rimas externas, a imitar, possivelmente, o vai e vem monocórdico do mar, ao qual se lançam os heróis da Ilíada trazida pela "bacante". O poema é todo construído sem o uso de letras maiúsculas, num efeito estético comum aos poemas de Moura e que auxilia a vagueza dos versos, que se confundem mais facilmente com as citações de Homero.

Assim, métrica e ritmo corroboram a um constructo próximo ao dos padrões clássicos, reforçados pela epígrafe, que será repetida durante a composição. É tecida, porém, uma trama com diversas camadas de referências literárias e históricas. Desta forma, entre a ironia e a dramaticidade, Moura guia o leitor a um caminho diverso ao da lira heroica que apresenta pela métrica e ritmo; imagens multifárias, que serão analisadas a seguir.

\section{Deuses e Reis: imagem e intertextualidade}

A diversidade, para Bhabha, é insuficiente para compreender-se a riqueza cultural poliédrica da contemporaneidade, na medida em que passa por uma compreensão de culturas totalizadas e separadas, que existem "intocadas pela intertextualidade de seus locais históricos, protegidas na utopia de uma memória mítica de uma identidade coletiva única" (BHABHA, 1998, p. 63). Esta diversidade não comporta uma noção de fronteira ou interação, onde "valores são (mal) lidos ou signos são apropriados de maneira equivocada" (BHABHA, 1998, p.63). O limiar onde a hibridização ocorre entre as diferentes culturas só é possível no que o autor chama de "diferença cultural" (BHABHA, 1998, p. 63), espaço de debate, crítica e, acima de tudo, de hibridização. Fala ainda de uma contenda entre duas formas de tempo, o das narrativas historicistas do tradicionalismo (de direita ou esquerda) e o tempo deslizante de uma política histórica de negociação (BHABHA, 1998, p. 64). A tradição pode surgir enquanto estratégia de representação da autoridade em termos do artifício do arcaico ou ser alargada por um retorno do mito, que celebra trajetórias de vida que seriam caladas no discurso monológico da história oficial. Temos, pois, o resgate de um passado utilizado enquanto forma retórica pela política e pelos que dela se servem para atingir o poder, ou pela cultura, enquanto tentativa do sujeito de uma descoberta de seu lugar na sociedade global, esboço de percepção do homem sobre si mesmo. Portugal desenterra os despojos do império para reconhecer-se em um tempo estático, como traz Lourenço em seus questionamentos sobre a identidade lusa:

A que se deve tão extraordinária capacidade de estar fora do tempo como presente numa época que se vive apenas como futuro e pura imprevisibilidade? [...] Ou íntima convicção de que, mesmo ganha, a nossa aposta num futuro incontornável nunca nos trará de volta aquela imagem que veneramos sob as várias metamorfoses de um Quinto Império? Isso explicaria não só o sucesso de todo o revivalismo que inunda hoje o horizonte da criação portuguesa, mas a sua consciente ou inconsciente deriva para lugares e tempos onde essa imagem se conserve ao abrigo da história, até da já transfigurada em mito (LOURENÇO, 2001, p. 109).

Se o mito sobrevivente no pensamento português é da ordem da nostalgia fantasmática dos mortos, o mito que vibra na letra de Moura é prenhe de vida, da ordem da comunhão entre homem e natureza e da eternidade que se faz presente. Estabelece-se, assim, na poesia de Moura, um espaço mítico, onde a realidade é desafiada por uma compreensão do homem e da natureza, que, não raro, manifestam-se em um mesmo plano de consciência e um tempo circular, onde passado e presente fundem-se e comungam de um único instante vivificador. Como já foi visto, Vasco Graça Moura se notabilizou não apenas por sua atuação poética e artística (quer crítica, quer criativa), como também por seu papel na política, que transcendeu as fronteiras lusitanas. Ferrenho defensor de uma identidade europeísta, vinculada à sua herança clássica, em vários momentos de sua obra, o autor sinaliza para uma nostalgia frente à erraticidade da cultura hipercontemporânea, global, digital e massificada. Para o autor, o velho espírito europeu ocidental é ameaçado, tanto pela deflagração da abertura cultural e informacional propiciada pela globalização quanto pela introdução de valores culturais, éticos e religiosos orientais, dentro deste 
cultivado Velho Mundo. Em contradição a este espírito protecionista do legado europeu, outro ponto tocado por Moura, em entrevistas e ensaios, é o do esgotamento do pensamento desta mesma Europa. Em trechos de entrevista dada ao blog "Visão", percebe-se facilmente a presença de dois sentimentos: o ressaibo de uma cultura cultivada e cultuada por Moura em toda sua trajetória, que ele próprio analisa como em franca decadência e a exaustão de caminhos:

A Europa problematizou praticamente todas as questões ligadas à condição humana. Na Europa, há valores religiosos, políticos e filosóficos que importa preservar. Não digo que todos devam ser cristãos. Eu, pessoalmente, não sou crente, mas os princípios da religião são fundamentais (MOURA, 2014, s.p.).

Ao mesmo tempo, Moura fala da necessidade de proteção deste legado frente a influências externas:

[...] com os fundamentalismos e a crise no Mediterrâneo, a integração da Turquia está a ser posta em causa, o que foi uma sorte para a Europa, evitar integrar habitantes extremamente pobres e de uma civilização completamente diferente da nossa. Não se pensou que a liberdade de comércio pudesse precisar de alguns travões, como não se pensou em políticas que preservassem os valores europeus (MOURA, 2014, s.p.).

Ironicamente, nem mesmo este sentimento de esgotamento/proteção frente a um patrimônio cultural e a uma história aparece como original. Ele próprio remeterá a um dos mitos fundadores da cultura europeia: do rapto de Europa e da trajetória de seu filho, Dioniso, em Tebas. Segundo Vernant (2000, p. 260), o retorno da divindade à sua terra natal contrapõe-se ao medo constante da alteridade complexa representada pelo "deus nascido duas vezes" (Dioniso). Esta será a hybris da tragédia que se deflagra a partir da rejeição dos grego ao deus orientalizado e ambíguo.

A volta de Dioniso para casa, em Tebas, esbarrou com a incompreensão e provocou um drama durante todo o tempo que a cidade foi incapaz de estabelecer o vínculo entre as pessoas da terra e o estrangeiro, entre os sedentário s e os viajantes, entre, por um lado, sua vontade de ser sempre a mesma, de continuar idêntica a si mesma, de se negar a mudar, e, por outro lado, o estrangeiro, o diferente, o outro (VERNANT, 2000, p. 160).

Moura parece ter esta percepção de sua própria contradição enquanto pensador, que aparecerá expressa nas inúmeras camadas de intertextualidade e simbologia propiciadas por "a bacante". As relações estabelecidas entre a atualidade política, acima problematizada pelo autor, em entrevista e a mitologia que cerca a figura de
Dioniso será, como veremos a seguir, eixo principal, uma das imagens recuperadas pelos versos do poeta. Analisemos, pois, as relações de significação evocadas pelas figuras construídas e reificadas constantemente em "a bacante" (2006, p. 128). O texto, como já vimos, principia com uma citação de Homero:

Logo que a fome apaziguada fica, Com puras libações se acaba a festa: Com vinho copioso em taça rica. Homero, Ilíada, tradução de Alcipe. (MOURA, 2006, p. 128).

Trata-se da estrofe de número 116 da Ilíada (s.d), momento em que os heróis comemoram antes de lançar-se ao mar. Neste momento, o irado Aquiles, afoito por iniciar sua aventura, recusa-se, em uma decisão que se mostrará pouco política (comum ao herói soturno), a comungar com seus guerreiros, antes de iniciar o ataque ao "Ílion" (Tróia).

Todorov lembra-nos que, no ato da interpretação, devemos atentar ao quadro ideológico proposto pelo autor, que nos permitirá delimitar o limiar da pertinência apresentado pelo texto, onde "o autor considera o saber partilhado por uma comunidade, com a sua memória coletiva (índices paradigmáticos)" (TODOROV, 1978, p. 28). Destarte, para a composição deste quadro ideológico, se faz necessária uma reflexão sobre a identidade do autor, ainda que não desprezemos a presença de um eu lírico dissociável do mesmo. Moura é um renomado tradutor. Nesta circunstância, não é por acaso que o poeta faz questão de manter a identidade do tradutor do poema-epígrafe, a poeta portuguesa Alcipe. Leonor de Almeida Portugal (1750-1839), poeta portuguesa de renome no Arcadismo, adotou o nome da filha de Ares em sua carreira literária. Acumulou aos títulos nobiliárquicos o de escritora e mulher das artes, tendo atuado ainda como tradutora de obras famosas, quer do francês, quer das línguas mortas, sendo, portanto, a um só momento, índice da aristocracia real e intelectual lusa. A menção à Alcipe pode ser percebida, neste contexto, como uma menção à nobreza, erudição e profundidade do pensamento português, uma tentativa de fortalecer a identidade lusa como notável dentro do legado europeu. Em uma estratégia poética utilizada em outros poemas de Moura, a epígrafe será introduzida a cada nova estrofe, doando sua cadência e métrica ao poema, adquirindo, cada vez que é retomada, um novo significado:

quando o talher pousado é o que resta

à noite do jantar dado em Benfica

a musa espevitada acorre lesta

e traz folhas de louro a cada testa

logo que a fome apaziguada fica

(MOURA, 2006, p. 128). 
Iniciam-se, então, os versos do poema, propriamente dito, com um talher, repousado ao prato - indicando o fim de um banquete. $\mathrm{O}$ poeta descreve uma ação e um espaço (uma situação), pois o banquete se dá em Benfica. Freguesia portuguesa do "concelho de Lisboa", é uma das mais populosas regiões lusitanas, e tem, acredita-se, em um banquete dado a D. Pedro I a origem de seu nome. Reza a lenda que Maria Rosada (assim chamada em alusão ao fato de ter sido forçada ao coito antes do casamento) e seu marido, dão um banquete ao rei, ocasião em que é descoberta pelo monarca a situação da anfitriã, desposada após a violação. O rei é irascível, aplicando o que estipula a lei, ou seja, o enforcamento do agressor. A esposa, já acostumada (ou enamorada) do marido e antigo algoz, acompanha em desespero o cortejo de execução e tenta impedir sua pena, ao que o monarca responde-lhe "Sossega mulher, que ele se vai e tu bem fica" (CASA BENFICA, 2014: s.p.). É interessante notar ainda que Rosada também é um dos títulos pelo qual ficou conhecida uma das mais cruéis das bacantes, descrita na obra poética destinada a estas personagens de autoria de Nono, de Panópolis (1940). Rode (a rosada), seria uma tíade (bacante) que teria o hábito de retirar a pele de suas vítimas com as próprias unhas, após forçá-las ao coito.

A figura da anfitriã do banquete irrompe como uma "musa espevitada", a "trazer louros a cada testa". Dentre as musas, como nos fala Hesíodo em sua Teogonia (1995), temos inúmeras qualidades, características e atributos. É Terpsícore (do grego "a que adora dançar") a mais irrequieta (espevitada) das entidades, em eterno movimento. À Terpsícore, musa da dança, é atribuída a maternidade das sereias (com o rio Aquéolo), seres mitológicos que atraíam os homens aos rochedos, com seu canto, para depois devorá-los. Eis que, após apaziguar a fome de seus comensais, a musa citada por Moura os orna com uma coroa de louros, ato que gera dupla possibilidade de interpretação. Dentre as musas, justamente Terpsícore ornou o filho de uma de suas irmãs com louros. É Orfeu (filho da musa da poesia, Calíope e do deus dos sonhos, Morfeu).

É interessante ainda que nos detenhamos sobre o ato da coroação com louros - em específico, da coroação dos comensais realizada pela anfitriã. Em sua obra "Métis, as astúcias da inteligência" Détienne e Vernant (2008) mostram um significado ao ato de coroar com louros, ação reificada, na tradição grega arcaica, em honra de Prometeu, aliado necessário, ainda segundo os autores, à conquista e manutenção do poder de Zeus. Seria em celebração ao titã que as cabeças seriam coroadas, em especial a dos hóspedes (xénoi), em uma artimanha dúbia. “Segundo 'Prometeu Libertado', é em honra de Prometeu que se coroa a cabeça 'antípoda toû ekeínou desmoû"" (DÉTIENNE e VERNANT, 2008, p. 88).
Os autores enfatizam este estatuto ambíguo relacionado a Prometeu. O pagamento deste liame seria um tributo instituído por Zeus, repetido como tradição em banquetes e eventos que envolvam xénoi, e relembraria o fato de que o deus dos deuses necessitou da capacidade de Prometeu (do grego, aquele que vê antes) de prever o futuro, evitando o nascimento do filho que o destronaria, conhecimento que apenas o titã carregava. Com este ato da coroação dos hóspedes e comensais, buscava-se representar a situação dúplice do estrangeiro ou convidado, que, a um só tempo, merecia ser homenageado, mas teria com seu anfitrião uma relação de dependência, pois, dentre os louros, esconder-se-ia o vime.

A coroa antiga de Prometeu não é feita de folhas de loureiro ou oliveira, como comumente, mas de vime (lýgos). [...] A coroa de vime liga-se a uma prática cultual da 'estátua acorrentada', rito sobre o qual não podemos aqui nos estender e que diz respeito em Samos ao ídolo arcaico de madeira, o brétas de Hera (DÉTIENNE e VERNANT, 2008, p. 88).

A dupla significação que encerra o ato dos anfitriões antigos, aparentemente, é carregado de múltiplas implicações no poema de Moura, que descortinará esta dubiedade ao leitor em sua próxima estrofe:
são só afagos suaves, ira honesta, tirados da bolsinha de peliça que a musa nessa altura nos apresta e se momentos houve só de trica com puras libações se acaba a festa (MOURA, 2006, p. 128).

Moura associa os "afagos suaves" a uma "ira honesta", que a anfitriã retira de uma "bolsinha de peliça". Não por acaso, as coroas são retiradas do repositário dos maiores artífices de uma cortesã, a bolsa onde guarda seus artigos de toucador, sua maquiagem. Estes "afagos suaves" são tratados como indício de uma "ira honesta" da "musa" que, ao fim do banquete, apesar de momentos de pura "trica" (intriga), parece querer terminar seu ágape com "puras libações". O autor marca, então, uma reviravolta na trama que desenvolve. Com um brinde, a "musa" irá metamorfosear-se em mênade (bacante ou tíade), como veremos, na última estrofe:

é quando erguendo a taça, que detesta criaturas menores ela explica e qual bacante os cantos purifica, julgando entre o que presta e o que não presta com vinho copioso em taça rica (MOURA, 2006, p. 128).

A anfitriã termina seu banquete com um brinde, afirmando "detestar criaturas menores". Neste momento, 
a intertextualidade do autor resgata uma cena da primeira obra atribuída a Shakespeare (de quem Moura é um dos mais célebres tradutores para a língua portuguesa), a tragédia Tito Andrônico (s.d.). Na peça, o poderoso general da Roma antiga, após cenas chocantes como decapitações e estupros, brinda sua inimiga, Rainha Tamora, com um banquete onde é servida à mãe uma torta feita do sangue, ossos e carne de seus próprios filhos, para que ela, involuntariamente, os devore. A obra, de crueldade pungente (uma das mais controversas peças shakespereanas), pode ser vista como metáfora à inabilidade com a cena política, por parte do enlouquecido Tito. O monarca julga, em sua loucura, seus inimigos, tal como o faz a "bacante", ao julgar o que "presta e o que não presta", no décimo quarto verso.

É quando surge, finalmente, a referência-título, e a anfitriã, de musa, torna-se uma bacante. Metáfora novamente circular, pois foram as tíades que mataram e devoraram o jovem e apaixonado Orfeu, após sufocarem, ou antes, "purificarem" (como fala o poema), seu canto irresistível com gritos, revoltadas por verem frustrada sua tentativa de seduzir o triste bardo. As bacantes são objeto da peça, de mesmo nome, de Eurípedes, frequentemente comparada à obra do estreante Shakespeare, por sua crua violência. Na tragédia grega, incitadas pelo enraivecido Dioniso, as bacantes, devotas tresloucadas do deus, invadem a casa real de Cadmo, seduzindo ao seu grupo a bela Ágave, irmã do antigo rei. Ágave entra, em uma das cenas finais, na sala do trono, com a cabeça de seu próprio filho, o monarca Penteu, por ela e as demais bacantes devorado.

Penteu, vítima e centro heróico da tragédia, é portador da hybris ambígua da repulsa ao estrangeiro, a xenofobia. A personagem tem "o desprezo por tudo que não é grego: os bárbaros da Ásia, lascivos, que tem a pele branca demais" (VERNANT, 2000, p. 155). Este medo exerce sobre o monarca, paradoxalmente, repulsa e atração. É por não resistir à tentação de observar a dança das bacantes que Penteu acaba por ser uma de suas vítimas. O rei é, a um só tempo, cônscio de seu papel de manutenção de uma hegemonia e vítima da fragilidade desta posição, que é desnudada pelo deus Dioniso, que, como nos lembra Vernant (2000), funciona como seu "duplo", espelho de suas contradições.

Penteu nutre a ideia de que o papel de um monarca é o de manter uma ordem hierárquica em que os homens estão no lugar que lhes cabe, as mulheres ficam em casa, os estrangeiros não são admitidos e em que a Ásia e o Oriente têm fama de serem povoados por gente efeminada, habituada a obedecer às ordens de um tirano, enquanto a Grécia é habitada por homens livres (VERNANT, 2000, p. 155-156).
É interessante ainda notar que, para Moura, o papel da bacante é o da "purificação dos cantos", ou seja, da elevação da poïesis através do dionisíaco que traz em si. Beber na "taça rica" da lira de Moura implica, desta forma, em revisitar o mito, o teatro e a poética ocidentais, convite a um banquete que não é isento de riscos.

Ao falar-se das bacantes, remete-se à "Dionisíaca", poema clássico atribuído a Nono, de Panópolis. Uma das mais famosas traduções da obra de Nono para a língua inglesa é atribuída a House (1940). O tradutor, em uma de suas notas, recupera o mito orfeista de Zagreu $^{2}$, filho de Perséfone e Zeus, que violentou sua mãe antes dela ser raptada por Hades. Instigados por Hera, os titãs teriam destroçado seu corpo, em vingança pelo crime. Seu coração, porém, que seria a essência dos vinhos, seria resgatado por Atena, e dado por Zeus, como uma bebida, a Sêmele, no intuito de embriagá-la, antes de gerar Dioniso.

Como vimos, esta intrincada teia de possibilidades intertextuais e imagéticas compõe um quadro rico em interpretações, alusão a um passado que permite o alargamento da interpretação do presente e uma (pré)visão de um futuro, um verdadeiro banquete de versos e (per)versões da história e da sociedade ao qual nos convida Moura, ao que se chega ao final deste olhar sobre o poema.

\section{0 prometeico, o (des)oriente e o (per)verso}

O filósofo da ciência Thomas Kuhn (1998) atribui à arte a mesma indústria do titã Prometeu, no que tange ao progresso científico, Para ele, o artista, ao imaginar o mundo, é capaz de antever uma realidade que ainda está por vir. É do artista o atributo de "ver antecipadamente" o que está por vir, ou seja, da pré-cognição (conhecer antes). Tal como ao titã, caberá ao artista, ainda, roubar o fogo dos deuses, levando ao homem o progresso. Esta antevisão é possível a qualquer momento, mas contumaz em períodos críticos, e acessível apenas àqueles que vivem na mimese do mundo imaginado. À visão dos artistas (livre das peias do mundo real, ao que Kuhn caracteriza literalmente como "pré-ciência"), segue-se o saber, que o autor declara como "ciência normal".

Para Kuhn (1988, p. 66), esta ciência terá respostas para os anseios da humanidade apenas por um período de tempo, ao que se seguirá nova "crise e revolução", que dará lugar a novos paradigmas, e a uma nova ciência. Eis um dos paradoxos do pós-modernismo, em sua tentativa de subverter uma realidade calcada em tradições que

\footnotetext{
O orfeismo (ou orfismo) é uma manifestação religiosa da Grécia, contemporânea à religião grega clássica, possuindo, porém, panteão ligeiramente diferente, e tendo teogonia própria, divergente da de Hesíodo, como nos trazem Bernabé e Casadesús (2009).
} 
ameaçam ruir, sem, porém, apontar uma nova direção. Ao caracterizá-lo, Todorov afirma que este pós-modernismo escaparia mesmo da visão de Kuhn, na medida em que não aponta novos caminhos, ao refutar os antigos.

Por ser contraditório e atuar dentro dos próprios sistemas que tenta subverter, provavelmente o pósmodernismo não pode ser considerado como um novo paradigma (nem mesmo até certo ponto da acepção kuhniana do termo). Ele não substitui o humanismo liberal, mesmo que o tenha contestado seriamente (TODOROV, 1978, p. 21)

O poema de Moura cabe perfeitamente na descrição de Todorov, ao flertar com o "bizarro" de que fala o autor (TODOROV, 1978, p.21). O poeta atua dentro de uma métrica e forma clássicas, remetendo o leitor a mitos e a um imaginário que igualmente servem de esteio para a cultura do Velho Ocidente. Os mitos aos quais o poeta se atém falam de um ocidente oligárquico e falocêntrico que se vê ameaçado por um oriente melífluo, feminino, a se materializar na figura de Dioniso e de suas bacantes. Nesta medida, a escrava oriental (a lídia escrava de Ricardo Reis) vista em "magusto de ricardo reis" (2006, p. 129) é tão ameaçadora quanto a mênade e anfitriã que o antecede, no poema "a bacante" (2006, p. 128).

$\mathrm{O}$ autor serve-se neste poema, assim como em outros de sua obra, de uma intertextualidade constante. Dioniso é filho da figura que dá nome ao velho continente, a princesa Europa. Em uma dança onde opostos se ameaçam, se antagonizam para enfim se confundirem, o autor fala da ira que se manifesta pela delicadeza de um afago, de uma honestidade expressa pelo artifício. A paradoxalidade é levada a extremos, a partir da combinação entre o intertextual e o imagético, entre o dito e o interdito.

A maternidade será anacronicamente aludida pela figura da mênade, sacerdotisa enlouquecida que convida a um banquete onde constantemente o canibalismo é sugerido de forma sutil, em um entretecer de significações que beira o aterrorizador, se atentar-se para os múltiplos e inegáveis índices que remetem à antropofagia, aliada à maternidade: a mãe das sereias - Terpsícore; a mênade que canibaliza seu próprio filho - figura central de "As bacantes"; a mãe lúbrica que deglute involuntariamente seus filhos em um banquete na tênue alusão à "Tito Andrônico" que reside no brinde, e, finalmente, última circularidade da qual faz-se nota, tem-se a legenda orfeista de Dioniso, trazido por House (1940). O poema teria, portanto, múltiplas alusões à antropofagia, ao estupro e a um matriarcado constantemente profanado.

Moura constrói uma ode ao medo do outro, que flerta permanentemente com os meandros da política. Estes meandros, aludidos em diversas ocasiões pelo europeísta, como no episódio do banquete dado a $\mathrm{D}$.
Pedro, ensejariam à Europa um inevitável fado, o de ser emasculada por sua própria curiosidade (tal como Penteu, ao travestir-se de mulher para contemplar as bacantes). Astutamente, o poeta leva o leitor a refletir não apenas sobre o sentimento de ameaça do Oriente que paira no espírito do Velho Mundo, mas sobre a perversidade constitutiva do espírito deste próprio europeu, que reifica, ao celebrar sua nobreza clássica, a herança do tresloucado Andrônico e do desafortunado Cadmo.

O poeta torna-se, ele próprio, um dos comensais da "bacante" que cria, a dançar sob a "lira" de que nos fala Paz, com a mesma mão que retesa o "arco" de Ares, em uma sobreposição voltaica de signos (1972). Seus versos são radicados em uma inevitabilidade que não apresenta quaisquer soluções, como é a poesia pós-moderna trazida por Todorov (1978). Assim, este poema tem como metáfora central a crise da identidade europeia do início do século XXI. Nesta obra, uma das últimas de sua vasta carreira, o poeta nos brinda com uma das maiores marcas da modernidade tardia ou hipercontemporaneidade, seu pessimismo, muitas vezes com um soturno um olhar para a contradição da condição humana.

Última dubiedade: notemos que o poeta carrega possíveis raízes muçulmanizadas, se levar-se em conta seu sobrenome (Moura), comum em terras ibéricas após a invasão dos mouros à Europa que marcou o fim do reino visigótico na península ibérica no ano de 711. Falecido no começo de 2014, Vasco Graça Moura descreveu uma trajetória de constante atualidade e mostrou, em seus inúmeros trabalhos, uma lucidez e um tenaz olhar para a realidade, que pareciam magicamente regenerados, a cada dia. O poeta permanecerá, em sua obra, imortalizado e preso a uma realidade da qual ameaça constantemente antever o futuro, como o trágico Prometeu, um titã acorrentado a uma contemporaneidade que o sobrepuja.

\section{Referências}

BERNABÉ, Alberto; CASADESÚS, Francesc. Orfeo y La tradición órfica. Um reencuentro. Madrid: Akal, 2009. Vol. 2.

BHABHA, Homi K. O local da cultura. Tradução de Myriam Ávila, Eliana Lourenço de Lima Reis e Gláucia Renate Gonçalves. Belo Horizonte: UFMG, 1998.

CASA BENFICA. História de Benfica. Disponível em: <http:// www.cbenfica.com/historia.html>, Acesso em: 27 jul. 2014.

DÉTIENNE, Marcel; VERNANT, Jean-Pierre. Métis - as astúcias da inteligência. HIRATA, Filomena. São Paulo: Odysseus, 2008.

GAGNEBIN, Jeanne Marie. Sete aulas sobre linguagem, memória e história. Rio de Janeiro: Imago, 1997.

GLADIUS. A última entrevista do falecido Vasco Graça Moura - um alerta contra a invasão. Disponível em: <http://gladio. blogspot.com.br/2014/04/a-ultima-entrevista-do-falecidovasco.html>, Acesso em 22 de julho de 2014. 
HOMERO. Ilíada. Tradução de Alcipe. Lisboa: Imprensa Nacional, [s.d.].

HESÍODO. Teogonia: a origem dos deuses. Estudo e tradução de Jaa Torrano. São Paulo: Iluminuras, 1995.

INSTITUTO CAMÕES. Vasco Graça Moura. Disponível em: $<$ http://cvc.instituto-camoes.pt/poemasemana/18/retratos1. html>. Acesso em: 27 jul. 2014.

KUHN, Thomas S. A estrutura das revoluções cientificas. Tradução de Beatriz Vianna Boeira e Nelson Boeira. São Paulo: Perspectiva, 1998.

LOURENÇO, Eduardo. A Europa desencantada: Para uma mitologia europeia. Lisboa: Gradiva, 2001.

MOURA, Vasco Graça. Poesia 2001/2005. Lisboa: Quetzal, 2006 .

PANOPOLIS, Nono. Dyonisiaca. Tradução de W. H. D. House. Cambridge (Massachussets)/London, 1940.
PAZ, Octavio. O arco e a lira. Tradução de Olga Savary. Rio de Janeiro: Nova Fronteira, 1972.

VISÃO. Vasco Graça Moura: A Portugal está a faltar muita poesia. Disponível em: <http://visao.sapo.pt/vasco-gracamoura-a-portugal-esta-a-faltar-muita-poesia $=\mathrm{f} 778411>$. Acesso em: 27 jul. 2014

SHAKESPEARE, William. Tito Andrônico. Tradução de Nelson Jahr Garcia. Rio de Janeiro: Ebooks do Brasil, s.d.

TODOROV, Tzvetan. Simbolismo e interpretação. São Paulo: Edições 70, 1978.

VERNANT, Jean-Pierre. O universo, os deuses, os homens. Tradução de Rosa Freire D’Aguiar. São Paulo: Companhia das Letras, 2000

Recebido, p. 21 de abril de 2016.

Aprovado, p. 28 de setembro de 2016.

Contato: jricardocostabg@gmail.com

\title{
APÊNDICE
}

\section{(ESCANSÃO DO POEMA "A BACANTE")}

\author{
a bacante \\ Logo que a fome apaziguada fica, \\ Com puras libações se acaba a festa: \\ Com vinho copioso em taça rica. \\ Homero, Ilíada, tradução de Alcipe
}

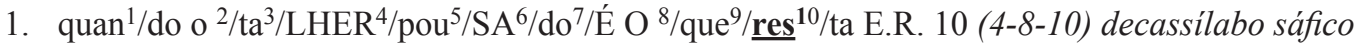

2. $\grave{a}^{1} / \mathrm{noi}^{2} / \mathrm{te}^{3} / \mathrm{do}^{4} / \mathrm{jan}^{5} / \mathrm{TAR}^{6} / \mathrm{da}^{7} / \mathrm{do} \mathrm{em}^{8} / \mathrm{Ben}^{9} / \underline{\mathbf{f}}^{10} / \mathrm{ca}$ E.R. 10 (6-10) decassílabo heróico

3. $\grave{a}^{1 /} \mathrm{mu}^{2} / \mathrm{sa} \mathrm{es}^{3} / \mathrm{pe}^{4} / \mathrm{vi}^{5} / \mathrm{TA}^{6} / \mathrm{da} \mathrm{a}^{7} / \mathrm{co}^{8} / \mathrm{rre}^{9} / \underline{\text { les }}^{10 / t a ~ E . R . ~} 10$ (6-10) decassilabo heróico

4. $\mathrm{e}^{1 /} / \mathrm{traz}^{2} / \mathrm{fo}^{3} / \mathrm{lhas}^{4} / \mathrm{de}^{5} / \mathrm{LOU}^{6} / \mathrm{ro} \mathrm{a}^{7} / \mathrm{ca}^{8} / \mathrm{da}^{9} /$ tes $^{10} /$ ta E.R. 10 (6-10) decassílabo heróico

5. $l o^{1} / g o^{2} / q u e a^{3} / F O^{4} / m e ~ a^{5} / p a^{6} / z i^{7} / G U A^{8} / d a^{9} / \mathbf{i}^{10} / c a$ E.R. 10 (4-8-10) decassilabo sáfico

6. são ${ }^{1} / \mathrm{SOCA}^{2} / \mathrm{fa}^{3} / \mathrm{gos}^{4} / \mathrm{SUA}^{5} / \mathrm{ves}^{6}, \mathrm{i}^{7} / \mathrm{RA}^{8} / \mathrm{ho}^{9} /$ nes $^{10} /$ ta, E.R. 10 (2-5-8- 5-10) decassílabo de arte maior ou E.R. 10 (5-10)

7. $\mathrm{ti}^{1} / \mathrm{ra}^{2} / \mathrm{dos}^{3} / \mathrm{da}^{4} / \mathrm{bol}^{5} / \mathrm{SI}^{6} / \mathrm{nha}^{7} / \mathrm{de}^{8} / \mathrm{pe}^{9} / \underline{\underline{i}}^{1} /$ ça E.R. 10 (6-10) decassilabo heróico

8. quea $1 / \mathrm{mu}^{2} / \mathrm{sa}^{3} / \mathrm{ne}^{4} / \mathrm{ssaal}^{5} / \mathrm{TU}^{6} / \mathrm{ra}^{7} / \mathrm{nos}^{8} / \mathrm{a}^{9} /$ pres $^{10} /$ ta E.R. 10 (6-10) decassílabo heróico

9. $\mathrm{e}^{1 /} / \mathrm{se}^{2} / \mathrm{mo}^{3} / \mathrm{men}^{4} / \mathrm{tos}^{5} / \mathrm{HOU}^{6} / \mathrm{ve}^{7} / \mathrm{só}^{8} / \mathrm{de}^{9} / \underline{\text { tri }}^{10} / \mathrm{ca}$ E.R. 10 (6-10) decassilabo heróico

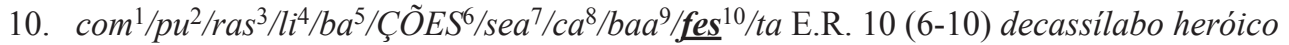

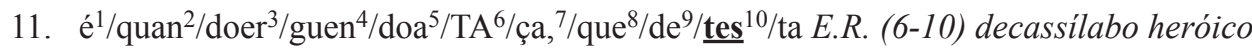

12. $\mathrm{cria}^{1} / \mathrm{TU}^{2} / \mathrm{ras}^{3} / \mathrm{me}^{4} / \mathrm{NO}^{5} / \mathrm{res}^{6} / \mathrm{E}^{7} / \mathrm{la}^{8} / \mathrm{ex}^{9} / \mathrm{pli}^{10} / \mathrm{ca}$ E.R. 10 (2-5-7-10) ou E.R. 10 (5-10)

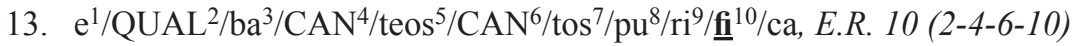

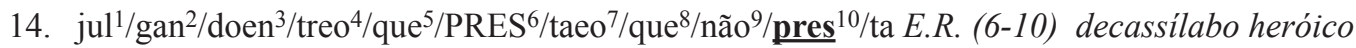

15. $\mathrm{com}^{1} / \mathrm{VI}^{2} / \mathrm{nho}^{3} / \mathrm{co}^{4} / \mathrm{PIO}^{5} / \mathrm{soem}^{6} / \mathrm{TA}^{7} / \mathrm{ça}^{8} / \underline{\mathbf{r i}}^{9} / \mathrm{ca}$ E. R. 10 (2-5-7-10) 